\title{
The Weaknesses of Euclidean Geometry: A Step of Needs Analysis of Non-Euclidean Geometry Learning through an Ethnomathematics Approach
}

\author{
Khathibul Umam Zaid Nugroho, a), Y. L. Sukestiyarno ${ }^{1}$, Adi Nurcahyo ${ }^{1}$ \\ ${ }^{1}$ Universitas Negeri Semarang \\ Sekaran, Gunung Pati, Semarang, Central Java, Indonesia, 50229 \\ a) khathibulumamzaidnugroho@students.unnes.ac.id
}

\begin{abstract}
Non-Euclidean Geometry is a complex subject for students. It is necessary to analyze the weaknesses of Euclidean geometry to provide a basis for thinking about the need for learning non-Euclidean geometry. The starting point of learning must be close to students' local minds and culture. The purpose of this study is to describe the weaknesses of Euclidean geometry as a step in analyzing the needs of non-Euclidean geometry learning through an ethnomathematics approach. This research uses qualitative descriptive methods. The subjects of this study were students of Mathematics Education at State Islamic University (UIN) Fatmawati Soekarno Bengkulu, Indonesia. The researcher acts as a lecturer and the main instrument in this research. Researchers used a spatial ability test instrument to explore qualitative data. The data were analyzed qualitatively descriptively. The result of this research is that there are two weaknesses of Euclidean geometry, namely Euclid's attempt to define all elements in geometry, including points, lines, and planes. Euclid defined a point as one that has no part. He defined a line as length without width. The words "section", "length", and "width" are not found in Euclidean Geometry. In addition, almost every part of Euclid's proof of the theorem uses geometric drawings, but in practice, these drawings are misleading. Local culture and ethnomathematics approach design teaching materials and student learning trajectories in studying NonEuclid Geometry.
\end{abstract}

Keywords: Ethnomathematics; Euclidean Geometry; Needs Analysis; Non-Euclidean Geometry

\begin{abstract}
Abstrak. Geometri Non-Euclid adalah mata pelajaran yang cukup rumit bagi siswa. Kelemahan geometri Euclid perlu dianalisis untuk memberikan dasar pemikiran tentang perlunya mempelajari geometri non-Euclid. Titik awal pembelajaran harus dekat dengan pikiran dan budaya lokal siswa. Tujuan dari penelitian ini adalah untuk mendeskripsikan kelemahan geometri Euclid sebagai langkah dalam menganalisis kebutuhan pembelajaran geometri non-Euclid melalui pendekatan etnomatematika. Penelitian ini menggunakan metode deskriptif kualitatif. Subyek penelitian ini adalah mahasiswa Pendidikan Matematika Universitas Islam Negeri Fatmawati Soekarno Bengkulu, Indonesia. Peneliti bertindak sebagai dosen dan instrumen utama dalam penelitian ini. Peneliti menggunakan instrumen tes kemampuan spasial untuk menggali data kualitatif. Data dianalisis secara deskriptif kualitatif. Hasil dari penelitian ini adalah terdapat dua kelemahan geometri Euclid, yaitu upaya Euclid untuk mendefinisikan semua elemen dalam geometri, termasuk titik, garis, dan bidang. Euclid mendefinisikan titik sebagai titik yang tidak memiliki bagian. Dia mendefinisikan garis sebagai panjang tanpa lebar. Kata-kata "bagian", "panjang", dan "lebar" tidak ditemukan dalam Geometri Euclid. Selain itu, hampir setiap bagian dari pembuktian teorema Euclid menggunakan gambar geometris, tetapi dalam praktiknya, gambar ini menyesatkan. Budaya lokal dan pendekatan etnomatematika merancang bahan ajar dan lintasan belajar siswa dalam mempelajari Geometri Non-Euclid.
\end{abstract}

Kata kunci: Analisis Kebutuhan; Etnomatematika; Geometri Euclid; Geometri Non-Euclid 


\section{INTRODUCTION}

Geometry learning is one of the mandatory materials for students. Geometry is an abstract subject that is difficult for students to learn (Widada, Herawaty, Ma'rifah, \& Yunita, 2019). It is necessary to analyze the weaknesses of Euclidean geometry to provide a basis for thinking about the need for learning non-Euclidean geometry. Geometry recognizes the properties of geometric shapes and objects (Maharani, Sukestiyarno, Waluya, \& Mulyono, 2018). Spatial ability is essential in understanding geometry and solving geometry problems (Eskisehir \& Ozlem, 2015). Spatial ability is a competency that must be possessed to understand geometry. Spatial thinking is a core skill of human life. It can be learned through formal education. Also, spatial abilities can be improved utilizing the tools and technologies planned in the curriculum (Yurt \& Tünkler, 2016). Learning geometry in a system presents its challenges for students (Widada, Herawaty, Widiarti, Aisyah, \& Tuzzahra, 2020). Learning Euclidean geometry and its comparison with non-Euclidean geometry is one of the exciting studies for students of mathematics and mathematics education.

Some weaknesses were found when studied from Euclid's Geometry (Byrne's Euclid, 1847; Heiberg, 1896). Euclid attempted to define all elements in geometry, including points, lines, and planes. Euclid defined a point as one that has no part. If asked what is meant by section? In Euclidean geometry, there is no explanation of "parts". The same thing happens when Euclid defines a line. He stated that a line is a length without width. It becomes a question of what is meant by "length" and "width". The explanation is not found in Euclidean Geometry. Therefore, learning about this and alternative non-Euclid geometry is necessary as an improvement material. Even though from the results of the research, when they are faced with learning Euclidean Geometry for the plane, students still have a reasonably good understanding, but when they start studying Non-Euclidean Geometry, they begin to have difficulty understanding it (Widada, Herawaty, Widiarti, Aisyah, \& Tuzzahra, 2020). Learning it requires good spatial skills.

Form and space are the primary studies of geometry. Therefore, learning requires good spatial ability (Güven \& Kosa, 2008). According to him, the spatial ability can improve students' attitudes to appreciate nature. There are many benefits of spatial ability in various fields like cartography, computer graphics, engineering, and architecture. Spatial ability is a powerful tool for understanding and solving geometric problems (Kayhan, 2005). Spatial ability is a cognitive process that is integrated with daily activities. In learning mathematics and geometry, representation and spatial thinking skills are needed (Eskisehir \& Ozlem, 2015). Spatial ability is the main factor of intelligence (Dilling \& Vogler, 2021). They further stated that learning that utilizes digital and computer media is needed to improve spatial abilities, such as the use of $3 \mathrm{D}$ printing technology in mathematics education. 
According to the theory of multiple intelligences, spatial intelligence has five components (Maier, 1998). These components are first, spatial perception, namely fixation of perpendicular and horizontal directions apart from troublesome information; second, visualization, namely the ability to describe the situation when the components move compared to each other; third, mental rotation. It is a mental rotation of three-dimensional solids; fourth, spatial relationship, as the ability to recognize the relationship between the parts of a solid object; Lastly, spatial orientation. Spatial orientation is the ability to enter certain spatial situations.

Spatial geometry is one of the most problematic mathematics learning materials (Bosnyak \& Kondor, 2008). One reason is that the concepts are complex, and the relationships between them are more complex. They suggested that lecturers motivate students to study spatial geometry actively. Geometric spatial ability is a mathematically structured complex unit of abilities and skills regarding various conceptions of shape, size, and position of spatial configuration; a firm illustration of a visible or imaginary configuration based on geometric rules; precise reconstruction of the clearly illustrated configuration; constructive solutions of different spatial problems, and the imagery and linguistic composition of these solutions.

The spatial ability must be developed early (Bosnyak \& Kondor, 2008). According to them, spatial representation conventions can be taught effectively at the age of 9-12 years. At the age of 12-14 years, visual representation and expression of three-dimensional space images can be taught well. According to the experience of an art lecturer, spatial representation must be taught to some children because they will never reach that level on their own. Therefore images and definitions of space are not innate. It is the result of a long developmental and experimental learning process.

According to Romberg and Kaput, school mathematics is a student activity as a reflection and process of mathematization like the work of mathematicians (Karadag, 2009). According to him, students seek new techniques to rediscover statements, concepts, and other mathematical objects in learning mathematics. Learning must start from concrete objects in daily life To improve mathematical representation (Widada, Nugroho, Sari, \& Pambudi, 2019). Learning mathematics is using mathematics to investigate problem situations. It is to decide on the variables and measure and relate them. Also, to perform calculations, make predictions, and verify the usefulness of predictions. Therefore, the ethnomathematics learning approach (Gravemeijer, 1994; Treffers, 1991) is more appropriate for teaching spatial geometry. Through this approach, students can represent mathematical activities horizontally and vertically to achieve formal mathematics (Freudenthal, 1991; Fauzan, Slettenhaar, \& Plomp, 2002).

Integrated learning based on daily life positively affects the ability to understand mathematics (Andriani et al., 2020). It is shown that the average score and understanding of mathematical concepts of students who are taught with realistic learning is higher than that of students who are taught using 
conventional learning models. Also, the average score of students' ability to understand mathematical concepts given local culture-based materials was higher than students who were not given local culture-based materials. This study shows that learning mathematics (including geometry) through a realistic approach can improve students' mathematical abilities. Other studies have consistently shown the same results. The mathematical understanding of students taught using realistic mathematics learning is higher than students taught using conventional methods (Widada, Herawaty, \& Lubis, 2018). Realistic mathematics learning with an ethnomathematics approach can be a vehicle for students to simplify the concept of functions to be more meaningful (Herawaty, Widada, Adhitya, Sari, \& Novianita, 2020). The student's mathematical process with an ethnomathematics approach can multiply two vectors that form right angles (Widada, Herawaty, Beka, Sari, \& Riyani, 2020). Another research is that there are differences in mathematical representation abilities between students taught by ethnomathematics approaches and conventional learning (Widada, Nugroho, Sari, $\&$ Pambudi, 2019). The results of this study consistently show that the ethnomathematics approach positively contributes to the improvement of mathematical ability.

Researchers are interested in describing the weaknesses of Euclidean geometry as a step in analyzing the needs of learning non-Euclidean geometry through an ethnomathematics approach. This research is the initial stage to find students' spatial thinking trajectory in understanding nonEuclid geometry through an ethnomathematics learning approach in terms of APOS theory and the problem-solving process. Learning geometry with a real-world approach broad concepts can be extended to other forms, like linking 'broad' with other 'big', investigating the relationship between area and perimeter, linking units of measurement to reality, and integrating some activity geometry (Fauzan, Slettenhaar, \& Plomp, 2002). In learning geometry (in general mathematics), the relationship with reality becomes a significant process. It emerges from the mathematization of reality, like Freudenthal's idea that reality as a framework is attached to mathematics itself (Gravemeijer, 2008; Plomp \& Nieveen, 2013). During the learning of geometry, we can interpret the process of student mathematization in solving problems or achieving certain concepts or principles. The cognitive process is a mathematizing process that can be analyzed through the student's genetic decomposition (Cooley, Trigueros, \& Baker, 2007; Widada, Herawaty, Widiarti, Aisyah, et al., 2020; Widada, Agustina, Serlis, Dinata, \& Hasari, 2019). Genetic decomposition is a structured collection of mental activities that a person does to describe how mathematical concepts/principles can be developed in his mind (Cooley, Trigueros, \& Baker, 2007; Widada, 2002). Genetic decomposition analysis is an analysis of a genetic decomposition based on the activities of actions, processes, objects, and schemes (APOS Theory) carried out by a person in mathematizing activities (Widada, 2017). 
According to Gardner's theory of multiple intelligences, distinguishing between the five branches of spatial intelligence (Bosnyak \& Kondor, 2008), namely spatial perception: fixation of vertical and horizontal directions despite troublesome information; visualization: it is the ability to describe situations when components move in comparison with each other; mental rotation: mental rotation of three-dimensional solids; spatial relationships: the ability to recognize relationships between solid parts; and spatial orientation: the ability to enter certain spatial situations.

The results showed that the ability of spatial visualization and mental rotation of prospective teachers was low; male teacher candidates have better qualifications than female teachers in mental rotation, but spatial visualization abilities do not differ by gender. Moreover, prospective teachers with higher academic averages have better spatial abilities. Integrating virtual environment applications such as Google Earth etc., into social studies courses and using them in these courses can help improve the spatial abilities of prospective teachers (Yurt \& Tünkler, 2016).

Another study stated significant differences between students' spatial visualization success concerning student gender, math achievement, interest in geometry, and level of visual/spatial intelligence. In addition, there is a positive, significant, but low correlation between the success of spatial visualization and the ability of students' visual/spatial intelligence (Eskisehir \& Ozlem, 2015). Spatial ability as an abstract concept which includes spatial relationships (the ability to observe the relationship of object positions in space), frames of reference (signs used as benchmarks to determine the position of objects in space), projective relationships (the ability to see objects from various points of view), distance conversion (ability to estimate the distance between two points), spatial representation (ability to represent spatial relationships by cognitive manipulation), and mental rotation (imagining rotating objects). Spatial ability also includes representing the world through mental images and artistic expression.

Indicator of spatial ability, according to Wahyudin (2015), is to state the position between the elements of a spatial structure; identify and classify geometric drawings; imagine the shape or position of a geometric object viewed from a certain point of view; construct and presenting geometric models drawn on a flat plane in the context of space; investigate a geometric object. A person's spatial ability can be known using a test or question. This test reveals something related to concrete objects through visualization. The type of question given will present a combination of the two previous approaches to measuring this ability.

The axiomatic deductive structure is built based on a basic concept that is not defined. It is an entity as a primitive concept. Objects that are primitive elements are interpreted without needing to be defined. It is intended to avoid the occurrence of circling the definition. The entity already has a precise meaning without any definition that limits it. After the basic concept, the axiomatic deductive structure is filled with the definition of a concept. It includes one or more boundaries of a concept. 
The relationship between concepts accepted as accurate without proof is an element that also builds the structure. It is an axiom that is needed to avoid circling the proof. The next element is the theorem. Theorems are true-valued statements that can be proved in a deductive structure.

Geometry is compulsory for mathematics education students (Nugroho, Widada, \& Herawaty, 2019). It is done through reflection on the students' initial abilities. Objects are abstract, so students often have difficulty understanding them (Widada, Herawaty, Nugroho, \& Anggoro, 2019). Therefore, teachers must be able to manage geometry learning appropriately. Teachers must carry out needs analysis, concept analysis, and task analysis (Nugroho et al., 2019).

Geometry is a deductive structure in mathematics. The structure starts from primitive elements consisting of points, lines, and planes. Axioms in geometry become basic statements. It is a true statement without being proven in its structure (Frassia \& Serpe, 2017). An axiom is a true statement that serves to avoid twisting the proof. In geometry, there is an understanding that limits a concept. That is a definition. Statements that are logical consequences in deductive structures in geometry are a theorem. The theorem must be proven true in the structure. Therefore, students must have mature cognitive processes (Dubinsky \& McDonald, 2000a). In addition, the research results Wu \& Ma (2006) suggested investigating why elementary school students had difficulty in quadrilaterals, and for advanced geometry, students had difficulty understanding and proving the properties of Sacherri quadrilaterals (researcher's initial survey). Preliminary findings indicate that quadrilaterals, except for squares and rectangles, are rarely shown in textbooks and their daily lives because students are psychological beings who can process information actively.

APOS theory describes developing mental structures at the level of processes, objects, and schemas (Maharaj, 2010). The APOS approach can give strong attention to students' mental and physical activities. It is primarily a verbal and graphic approach to finding functional limits, dismantling a given structure in symbolic form, and modeling possible schematics. However, it takes a starting point that is easy and close to students' minds. Therefore, the ethnomathematics approach can supplement the application of APOS Theory.

Ethnomathematics studies the cultural aspects of mathematics (Rosa \& Orey, 2011). According to Rosa \& Orey, ethnomathematics presents mathematical concepts from the school curriculum in a way in which these concepts are related to the culture and daily experiences of students, thereby increasing their ability to decipher meaningful relationships and deepening their understanding of mathematics. The ethnomathematics approach to the mathematics curriculum is intended to make school mathematics more relevant and meaningful to students and improve their education's overall quality. In this context, applying an ethnomathematics perspective in the school mathematics curriculum helps develop students' intellectual, social, emotional, and political learning 
by using their unique cultural references to convey their knowledge, skills, and attitudes. This kind of curriculum provides a way for students to maintain their identity while succeeding academically.

The extended idea of ethnomathematics as dealing with students' daily mathematical practice has equality of all students as its primary goal (François, 2010). Furthermore, François (2010) states that ethnomathematics is a philosophy of mathematics education where mathematical literacy is a fundamental right of all students. The teaching process tries to reach all students and involve them in learning mathematics, regardless of their cultural diversity. All students are the same. This notion of mathematics for all is compatible with the ethical concept of pedagogical optimism associated with the theory of egalitarianism. The ethical-theoretical foundation assumes that equality is measured at the end of the line.

Learning mathematics through an ethnomathematics approach can improve students' cognitive processes. A comprehensive understanding of cognition and learning mathematics refers to various theoretical frameworks on abstraction (Nugroho et al., 2021). Various aspects have implications for the formulation of a mathematics learning culture. Various focuses on several aspects of ethnomathematics are language and communication in mathematics education, equality, diversity, and learning in multicultural mathematics classrooms. These topics will thus not be the focus of this chapter, although some of the issues from these areas will enter spontaneously (Kleinman, 1987).

The results showed that students could connect these elements to form a coherent whole based on observations of lontong (a rice cake). They produce a new product by organizing several elements into a different shape or pattern than before, namely a triangle with a large number of angles less than 180. Students' understanding of triangles in Lobachevsky Geometry has reached the level of creation. A new proposition, i.e., the sum of the angles in a triangle in Lobachevski geometry, is less than 180 (Widada, Herawaty, Hudiria, Prakoso, et al., 2020). Another study states that learning realistic mathematics with an ethnomathematics orientation can improve the mathematical problemsolving ability of high school students (Lubis, Widada, Herawaty, Nugroho, \& Anggoro, 2021). Also, Tabot Culture strengthens students' character who obey principles, think logically critically, work hard, have curiosity, independence, and self-confidence. The geometric concepts in the Tabot culture are cubes, blocks, pyramids, prisms, spheres, and their elements. Understanding of two-dimensional figures. The Bengkulu Tabot culture can be used as a starting point for learning the achievement of geometric concepts and strengthening students' character (Agusdianita et al., 2021). Thus, learning mathematics through an ethnomathematics approach is feasible in understanding Non-Euclidean Geometry.

The research results on the mathematization process are analyzed by genetic decomposition, such as research (Widada, 2011). The research found several conclusions. Among others, students could only perform the action-process separately on the function's properties, and the action-process 
was described at intervals-by-interval separately as well. This fact shows that he does not understand conceptually. Some students can coordinate action-process for two or more different properties of a function, but not all properties of a given function. However, the coordination is described on a separate interval-by-interval basis. Based on the conception of the process, he can form a conception of the object. Some students can encapsulate the action process for two or more properties of a function, but not all properties of a given function. The coordination is described in two or more adjacent intervals or overlapping domains so that an object is formed about the function graph sketch. To build an object on the function graph sketch, some students can coordinate the action process or an object of two or more functional properties. This finding is particular research on the substance of calculus and analytical geometry.

In previous research, the genetic decomposition of students was only classified into three levels called the triad level (Dubinsky \& McDonald, 2000a; Dubinsky, Dautermann, Leron, \& Zazkis, 1994a; Dubinsky, Dautermann, Leron, \& Zazkis, n.d.; Hankeln, 2021; Dubinsky, Weller, McDonald, \& Brown, 2004; Dubinsky \& Wilson, 2013; Dubinsky \& McDonald, 2000b; Dubinsky, Dautermann, Leron, \& Zazkis, 1994b). The triad level is the intra-level, inter-level, and trans-level. The research refers to the substance of arithmetic, algebra, and calculus. They reveal that all conceptions of cosets, together with the properties understood by individuals, will be organized in a schema about cosets, i.e., a system of actions, processes, objects, and other schemas related to cosets, as well as coordination carried out by individuals as a form of cosset —understanding of cosets. In addition, genetic decomposition can describe the characteristics of cognitive processes that are classified into the extended-triad level (Widada, 2016). It is a cognitive level consisting of seven levels: Pre-Intra Level, Intra Level, Semi-inter Level, Inter Level, Semi-trans Level, Trans Level, and Extended-Trans.

This leveling is also in the realm of real analysis. Therefore, this research is reinterpreting a possible theory in a different context. The different contexts are geometric substance and spatial ability. Thus, this paper discusses how students' spatial abilities during geometry learning through an ethnomathematics approach are reviewed from the APOS Theory.

Thus, the focus of this research is "weaknesses of Euclidean geometry as a step in analyzing the needs of learning non-Euclidean geometry through an ethnomathematics approach". The focus of this research is part of our other research design (Nugroho et al., 2021) with the framework as set out in Figure 1. 


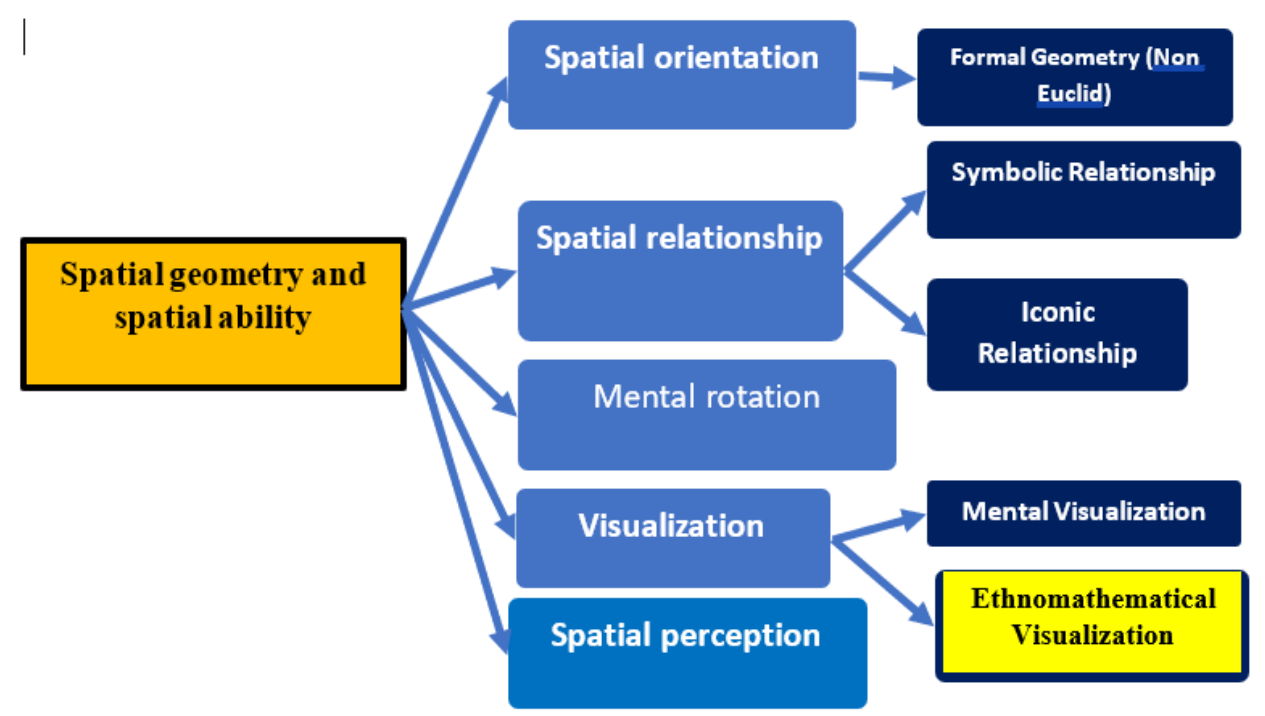

Figure 1. Geometry Spatial Ability Development Framework

Based on Figure 1, the focus of this research is ethnomathematics visualization (see yellow rectangle). It analyzes student needs in interpreting geometric objects visually through an ethnomathematics approach.

\section{METHOD}

This research uses qualitative and quantitative descriptive methods. This research aims to explore students' spatial abilities after learning geometry through an ethnomathematics approach in understanding non-Euclidean geometric concepts. Learning is carried out online to comply with the COVID-19 health protocol. This research also has exploratory characteristics. The subjects of this study were students of Mathematics Education at UIN Fatmawati Soekarno Bengkulu, who studied non-Euclidean geometry through an ethnomathematics approach. I am a researcher and act as a lecturer whose role is to carry out learning, collect data and triangulate the interpretation of student work. The researcher acts as a teacher and the main instrument in this research. Researchers are as open as possible in the process of data collection and data analysis. Researchers contributed to data collection by designing learning, research, and procedures and conducting tests and in-depth interviews with students. Researchers used a spatial ability test instrument to explore qualitative data. It is independent of the quantitative assessment rubric associated with the qualitative analysis of the qualitative data collected in this study. Quantitative data is used as a basis for determining research subjects who will be interviewed in-depth to explore students' spatial abilities during geometry learning through an ethnomathematics approach or local context (Junarti, Sukestiyarno, Mulyono, \& Dwidayati, 2020).

Learning is conducted online with 30 students participating in Mathematics Education at UIN Fatmawati Soekarno Bengkulu, Bengkulu, Indonesia. Online learning was chosen because it can 
improve students' creative thinking skills (Sukestiyarno, Mashitoh, \& Wardono, 2021; Maharani \& Sukestiyarno, 2017; Ishak, Sukestiyarno, Waluya, Rochmad, \& Mariani, 2021). We use zoom meeting media to carry out learning. We were also supported by WhatsApp groups, YouTube, and email. Learning is carried out for four meetings in two weeks. After the lesson was over, we held a spatial ability test via google forms for all 30 students. The test results were analyzed using the existing assessment rubric. From the results of the quantitative analysis, we grouped them into three categories, namely high, medium, and low groups. Each group purposively selected one student who volunteered for an in-depth interview. The three subjects of this study were JK, ST, and YP. Interviews were conducted using WhatsApp via video calls. This in-depth interview was conducted to explore and triangulate research data. It is a means to explore students' spatial abilities. This interview was recorded to obtain complete and accurate data.

In collecting data, I sent a google form link from the research instrument to students about the spatial ability test as many as ten multiple-choice test items and fill in the reasons for choosing students to choose the answer items. The arguments in the reason column are made open for students to explore. Open fields that have specific answers according to the student's cognitive process. I developed ten test items in google forms to make it easier for students to work on questions and give time with a specific limit.

Research data is analyzed through genetic decomposition analysis (Widada, Herawaty, Jumri, $\&$ Wulandari, 2020). Genetic decomposition describes actions, objects, processes, schemes, and the relationships individuals have for concepts and principles in spatial geometry. Learning geometry through an ethnomathematics approach gives students the experience to construct actions, processes, objects, and schemas and organize them in a coherent schema. It was a mature scheme (Widada, Herawaty, Nugroho, \& Anggoro, 2019; Widada, Efendi, Herawaty, \& Nugroho, 2020). We analyzed the data using genetic decomposition analysis techniques describing each research subject categorized in an action-process-object scheme (Dubinsky \& McDonald, 2000b) (Baker, Cooley, \& Trigueros, 2000). Each stage of the action-process-object and schema can be described in actual activities (Widada, 2011; Widada, 2007; Widada, 2002). The quote describes as follows: action is a procedural activity through physical repetition of mental manipulation to transform objects in several ways. An indication is to react to the received external stimulus in the form of a complex expression of the steps that must be carried out. Interiorization is a change in activity from a procedural activity to being able to re-enact activities in imagining several meanings that affect the resulting conditions (a form of action in the process) as an indication is to make a change in activity from an action to an activity that is carried out internally (imagined in mind). Suppose the entire action can be placed in the individual's mind or imagined without doing the whole of certain stages. In that case, after being interiorized, the action becomes a process as an indication is to carry out internal activities but not 
necessarily directly from external stimuli (not all stages are done explicitly). Encapsulation is a process performed on objects as an indication is to carry out a mental transformation (in the form of cognitive coordination) of a process on a cognitive object. If some action transforms the process itself, an encapsulation that matches an object as an indication is the formation of a single entity from the encapsulation of several processes. Thematization is a construction that links separate actions, processes, or objects to a particular object to produce a schema as an indication is the formation of a total entity from different objects constructed through cognitive coordination. A mature schema of a mathematical fragment is a coherent system of actions, processes, objects, and other schemas that have been built previously, which are coordinated (synthesized) by individuals in the form of structures that are used to deal with specific problems situations. Certain pieces of mathematics contain a broader meaning than mathematical objects (facts, concepts, principles, and rules) but include one's conception of mathematical objects, as well as other fragments related to problemsolving. As an indication, it can solve problems related to the objects that build the intended schema and solve these problems using rules, no longer by registering.

Furthermore, reflection for each category that arises from each stage either moves to another cycle or completes the analysis. This reflection is based on comparing the categories of genetic decomposition of each subject with those obtained previously to see if the categories are saturated and answer the research questions. Thus, qualitative analysis of data relies on the researcher's description and interpretation of the data through the perspective and knowledge of the researcher.

\section{RESULTS AND DISCUSSION}

Geometry learning through an ethnomathematics approach for Mathematics Education students at UIN Fatmawati Soekarno Bengkulu, Indonesia, is carried out online. Lecturers who play a role in carrying out learning are researchers. They are also a data collector and conduct in-depth interviews based on interpretations of student work. Thirty students take part in the study. The implementation of learning is four meetings in October 2021.

The researcher conducted a needs analysis and studies on the weaknesses of Euclid's Geometry based on his book entitled "The Elements of Euclide" (Byrne's Euclid, 1847; Heiberg, 1896). Based on the content analysis in the book, show that Euclid tried to define all elements in geometry, including points, lines, and planes. Euclid defined a point as one that has no part. If asked what is meant by section? In Euclidean geometry, there is no explanation of "parts". The same thing happens when Euclid defines a line. He stated that a line is a length without width. It becomes a question of what is meant by "length" and "width". The explanation is not found in Euclidean Geometry. 
Euclid's proof of the theorem, almost every part uses geometric drawings, but in practice, the drawings are misleading. For example, prove Theorem 1: "In a triangle, if one of the sides is extended, then the exterior angles of the triangle are greater than the non-adjacent interior angles." Euclid proves this is using the illustration in Figure 2.

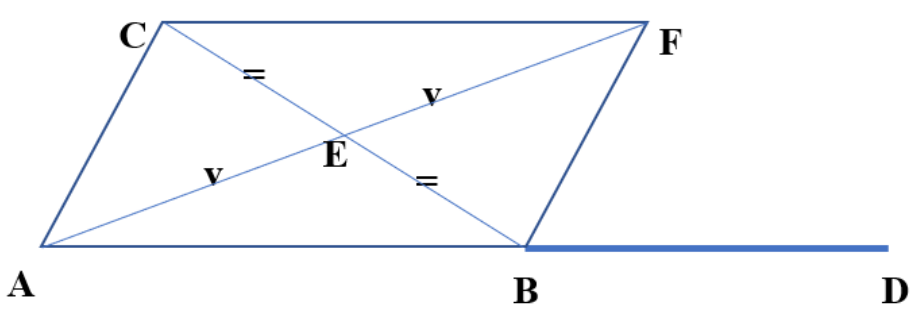

Figure 2. Illustration of Proof of Theorem 1

Two different angles are called contiguous if the two angles are adjacent and are supplementary (angle DBE is adjacent to angle ABE, but DBE is not adjacent to angle ACE, ACE is one of the angles in triangle $\mathrm{ABC}$ ). Euclid proved that the angle $\mathrm{DBE}$ is also greater than the angle $\mathrm{ACE}$. The proof is as follows. Based on the triangle $\mathrm{ABC}$ (See Figure 1), first extend side $\mathrm{AB}$ to point $\mathrm{D}$. Take the midpoint of side $\mathrm{BC}$, for example, point $\mathrm{E}$. Extend line $\mathrm{AE}$ such that $\mathrm{AE}=\mathrm{EF}$, and get triangle ACE equal to and congruent with triangle BFE (based on the axioms of sides, angles, sides; that is, side $\mathrm{AE}=\mathrm{EF}$, angle $\mathrm{AEC}=$ angle $\mathrm{BEF}$, and side $\mathrm{BE}=\mathrm{EC})$. This statement means that the angle $\mathrm{ACE}$ is the same as FBE. Furthermore, the DBE angle must be greater than the FBE angle, and the DBE angle must also be greater than the ACE angle (proven).

Based on the evidence, it shows that the steps are not given a valid argument. For example, "the angle DBE must be greater than the FBE". In this case, Euclid unwittingly applied the principle of space separation. If you do not use this principle, point $\mathrm{F}$ is impossible in the BDE angle. This argument will invalidate the proof. The evidence is misleading.

Other examples are as follows. Let $\mathrm{ABC}$ be an arbitrary triangle. Then it is illustrated in Figure 3.

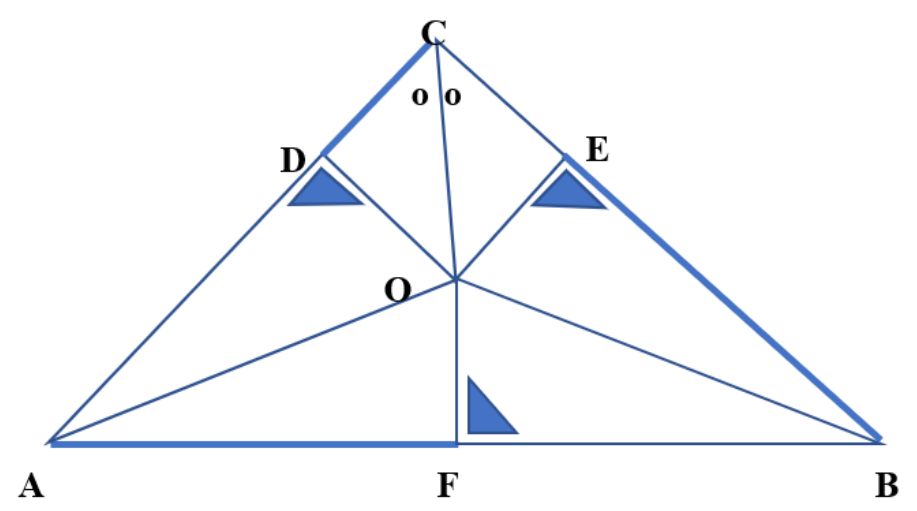

Figure 3. Any Triangle ABC 
Take $\mathrm{F}$ the midpoint $\mathrm{AB}$. Draw a line $\mathrm{OF}$ perpendicular to $\mathrm{AB}$ and $\mathrm{OC}$, the bisector of angle ACB. Draw a line OD perpendicular to AC. Pull OE perpendicular to BC. Connect AO and BO so that triangle COD is equal and congruent with triangle CDE (axioms of angles, angles, sides). Consequently, $\mathrm{DO}=\mathrm{EO}, \mathrm{DC}=\mathrm{EC}$, and triangle $\mathrm{AFO}$ is congruent with triangle $\mathrm{BFO}$, so $\mathrm{AO}=\mathrm{BO}$. Triangle $\mathrm{ADO}$ is congruent to triangle $\mathrm{BEO}$, so $\mathrm{AD}=\mathrm{BE}$. Consequently, $\mathrm{AD}+\mathrm{DC}=\mathrm{BE}+\mathrm{EC}$ which means $\mathrm{AC}=\mathrm{BC}$. In the same way, we get $\mathrm{AB}=\mathrm{BC}=\mathrm{AC}$, meaning triangle $\mathrm{ABC}$ is equilateral. Since $\mathrm{ABC}$ is an arbitrary triangle, the conclusion is that every triangle must be equilateral. This conclusion is so confusing because impossible that every triangle is equilateral. This proof does not use valid arguments. Pay attention to the proof step "Draw the line OF perpendicular to AB and OC bisectors of angle ACB" because it is not necessarily OC and OF intersect in the area in triangle ABC. Therefore, this step is not based on valid arguments. As a result, the conclusion that every triangle is equilateral is wrong. This weakness is the first step to designing Non-Euclid Geometry learning through a more contextual and meaningful learning approach.

Furthermore, at the end of October 2021, we held a spatial ability test via google forms for all 30 students. It is a test of understanding concepts and principles in Euclidean geometry. The results of the analysis of the test data, students were grouped into three categories, namely high, medium and low groups. The results of this grouping can be seen in Figure 4.

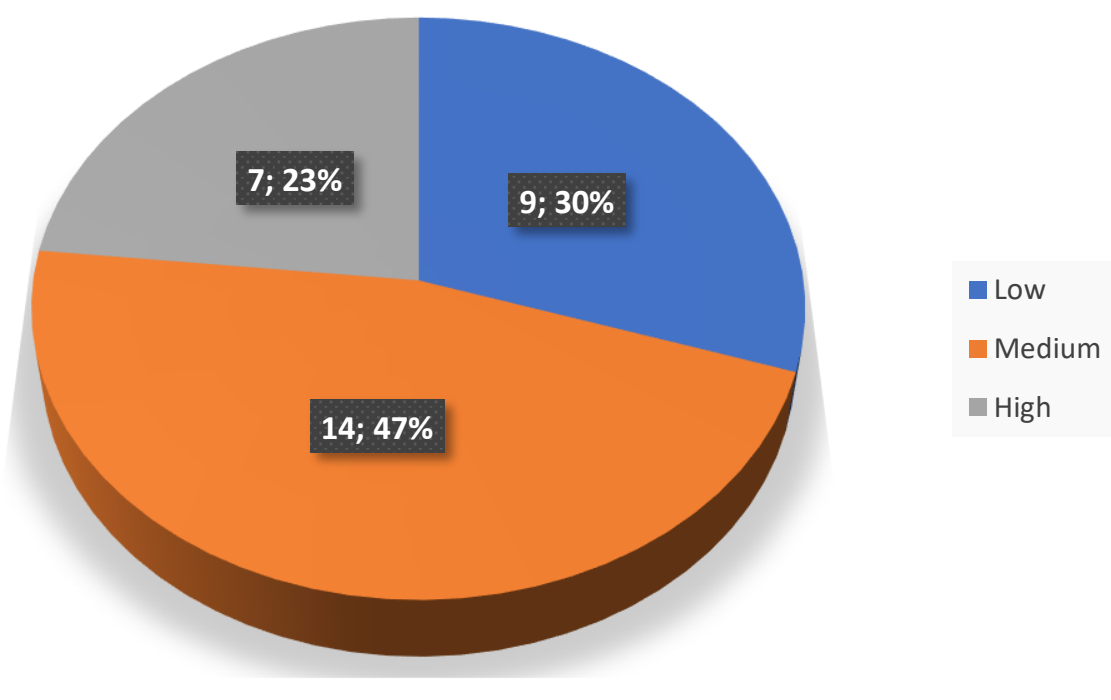

Figure 4. Percentage of Students' Spatial Ability

Figure 4 shows that $23 \%$ or as many as seven students have high spatial abilities. There are $30 \%$ (as many as nine students) who have the low spatial ability, and $47 \%$ of students have moderate spatial ability. Based on the grouping of students, we selected one student who volunteered to be interviewed in-depth. This study has three subjects, namely JK, ST, and YP. The selection technique has been described in the method. They were interviewed separately via video call and recorded with WhatsApp media. That is to produce interview data on research subjects, paper and pencil, and 
students' physical and mental activities regarding spatial understanding abilities. Based on qualitative data analysis, samples from genetic decomposition analysis samples were presented from JK, ST, and YP subjects. $\mathrm{R}$ is the interviewer.

\section{Footage 1}

Researcher : "Please explain Problem 1 on your assignment sheet."

JK : "Yes Sir! Based on Problem 1, it is known that the cube ABCD.EFGH has side a cm. $\mathrm{P}$ is the point where the two diagonals of the EFGH plane intersect. The question is the distance from point $A$ to point $C$, point $A$ to point $G$, and point $A$ to point $P$ ? That, Sir, I understand."

Researcher : "Okay! Please explain what you are doing!"

JK : "I tried to draw the cube according to what I knew." [JK while pointing at his work, namely Figure 5]

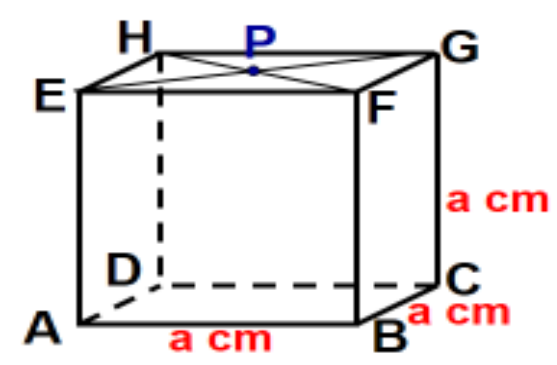

Figure 5. JK's Cube

Based on Excerpt 1 and Figure 5, JK can understand the questions given and represent them through spatial perception. It produces a correct spatial image. He states the position between the elements of a building placed in a horizontal or vertical position. JK has good spatial perception. He can perform actions on the elements of the cube space perform Interiorization in the form of compiling the relationship between vertical and horizontal lines. It is the encapsulation of the geometric object named cube ABCD.EFGH and the thematization between the diagonal principles of the plane and forming a schema about the cube properties.

The description of Footage 1 of the action-process-object activity and the schema shown by JK means that JK can coordinate spatial objects into a mature schema. It's a trance level (Widada, 2016; Widada, Herawaty, Nugroho, \& Anggoro, 2019; Widada, Herawaty, Anggoro, \& Nugroho, 2019). Next, JK explained the solution to Problem 1. Look at the following Footage 2.

\section{Footage 2}

JK : "Based on Figure 5 and the question in Problem 1, I have to determine the diagonal AC and the diagonal of the space AG."

Researcher : "Okay!" 
JK

: "You can see Figure 5 then notice that triangle $\mathrm{ABC}$ is right-angled at $\mathrm{B}$, with length $A B=A C=a \mathrm{~cm}$. That means the length of $A C$ is the root of $\left(a^{2}+a^{2}\right)$ i.e., the root of $2 \mathrm{a}^{2}$. It can be simplified to $\mathrm{AC}=\mathrm{a} \sqrt{2}$."

Researcher : "Okay. Let continue."

JK : "Yes Sir. Notice the triangle ACG in Figure 5, a right triangle in C, where AC $=a \sqrt{2}$ and $C G=a$, it means that the length of $A G$ is the root of $\left(2 a^{2}+a^{2}\right)$. It is the root of $3 a^{2}$. It is that $A G=a \sqrt{ } 3 . "$

Researcher : "Okay. Good job. Let continue."

JK

: "Next, based on Figure 6, please look at the triangle AEP. It is a right triangle at $\mathrm{E}$ and the distance from point $\mathrm{A}$ to point $\mathrm{P}$ is the root of $\left(\mathrm{AE}^{2}+\mathrm{EP}^{2}\right)$. based on the diagonal property of the side of the cube, then $\mathrm{EP}=\mathrm{EG}$ while $\mathrm{EG}=\mathrm{AC}=\mathrm{a} \sqrt{2}$. It means $\mathrm{EP}=$ $\mathrm{a} \sqrt{2}$. Based on these data, then AP is the root of $\left(a^{2}+(1 / 2 a \sqrt{ } 2)^{2}\right)$. If I calculate, then $A P=$ a 6 . All measurements are in centimeters."

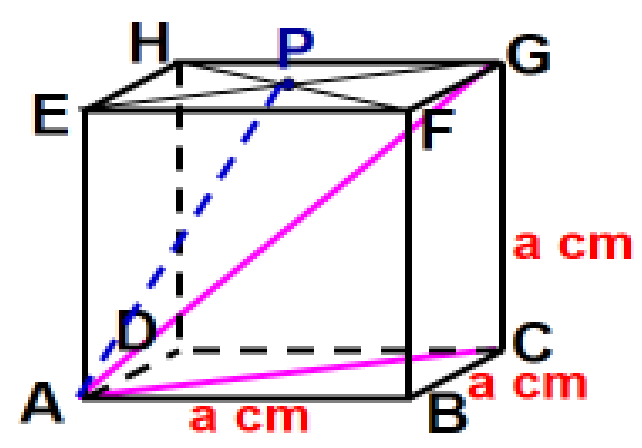

Figure 6. Visualization of the Cube Space

Footage 2 and Figure 6 show that JK has a mature schema about the properties of the geometric shape (cube). Thematization of objects about the diagonal of the plane and the diagonal of space can be represented in a good mental activity. He can predict the image of the shape of the space correctly. It is a spatial visualization, as represented in Figure 6. He can construct and present cube models drawn on the data plane. JK can draw the shape or position of a cube object from a certain point of view. It is a rotation of the mind. JK also draws the shape or part of the object and the relationship between the parts. That is the spatial relation shown by JK. Based on JK's description, he has a high spatial ability. It is shown based on paper-and-pencil as well as mental activity. This fact is a success of realistic learning in improving students' spatial abilities through learning geometry. It is a description of spatial ability confirmed to be an essential component of intelligence and a predictor of success in learning geometry (Marunić \& Glažar, 2014). The research results that the development of visualization skills can be achieved well. That is the specific goal of learning modern engineering graphics and spatial reasoning. It is also a core competency for the relevance of future abilities in understanding and applying spatial abilities in daily life. 
Geometry learning with an ethnomathematics approach gives a real contribution to JK's spatial ability. Because so far, geometry learning in Indonesia is taught with a structuralistic approach and is very theoretical. There are problems in learning geometry in schools in Indonesia (Fauzan, Slettenhaar, \& Plomp, 2002). They stated that the approach to learning geometry is very theoretical. It is a learning that presents many abstract concepts and formulas that are introduced without paying much attention to logic, reasoning, and understanding.

Interviews with students with moderate geometric abilities were described according to their mental and physical activities. The research subject is ST. He described the room's layout well but had problems in solving the problems given. ST understands the problem given but has difficulty connecting geometric objects of space. As a result, they experience errors in concepts and principles. Here is a snippet of the interview.

\section{Footage 3}

Researcher : "Good afternoon ST, please explain how about Question 2 that I gave you?"

ST : "Yes, Sir, good afternoon. From Problem 2, it is known that the cube ABCD.EFGH with side length $5 \mathrm{~cm}$. Is asking the distance from point $\mathrm{A}$ to edge $\mathrm{HG}$ and the distance from point B to the diagonal of space AG?"

Researcher : "Okay, well. How do you answer that?"

ST : "First, let me draw the cube. You see Figure 6."

Researcher : "Okay, continue."

ST : "First, I calculate the distance from point A to the edge of HG is the length of the line segment $\mathrm{AH}$. $\mathrm{AH}$ is perpendicular to $\mathrm{HG}$. $\mathrm{AH}$ is the root of 2 times 25 , which is the root of 50 which is the distance A to $\mathrm{HG}=5 \sqrt{2} \mathrm{~cm}$ "

Researcher : "Okay. Answer the following question?"

ST : "The distance from point B to the diagonal AG. How do I explain it, Sir?"

Researcher : “...”

ST : "I calculated it using the diagonals HB and AG. Suppose the intersection of the two diagonals of the space is point $\mathrm{P}$, then the distance in question is $\mathrm{BP}$ and $\mathrm{BP}$ is half the diagonal of a cube with edges $5 \mathrm{~cm}$. So the distance from point $B$ to $A G$ is of $5 \sqrt{3} \mathrm{~cm}$ that is $2.5 \sqrt{ } 3 \mathrm{~cm} . "$ 


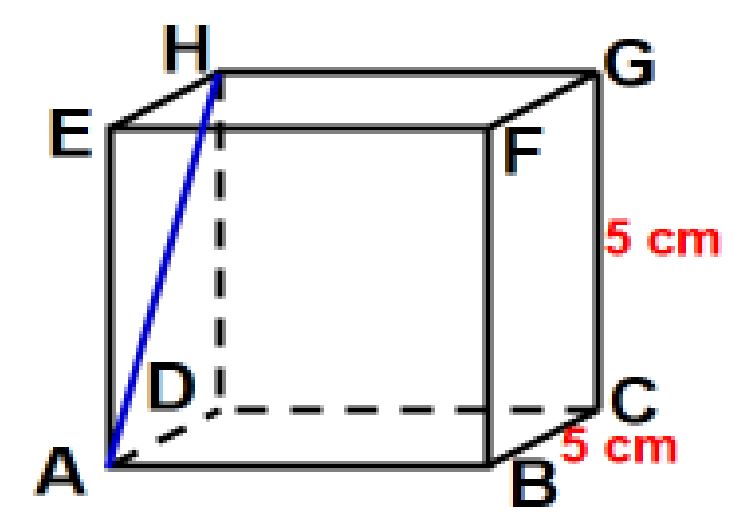

Figure 7. Representation of Cube ABCD.EFGH with Edge $5 \mathrm{~cm}$

Footage 3 and Figure 7 mean that ST students can carry out action-process-object-and schema activities, but the thematization is not complete. As he stated, "First I calculate the distance from point $\mathrm{A}$ to the edge $\mathrm{HG}$ is the length of the line segment $\mathrm{AH}$. $\mathrm{AH}$ is perpendicular to $\mathrm{HG}$. $\mathrm{AH}$ is the root of 2 times 25 that is the root of 50 that is the distance $A$ to $H G=5 \sqrt{ } 2 \mathrm{~cm} "$. As a result, the scheme obtained is not mature. It can be seen from the description that "I calculated it using the diagonals HB and AG. Suppose the intersection of the two diagonals of the space is point $\mathrm{P}$, then the distance in question is BP and BP is half the diagonal of a cube whose edges are $5 \mathrm{~cm}$ so the distance from point $B$ to $A G$ is of $5 \sqrt{3} \mathrm{~cm}$. That is $2.5 \sqrt{3} \mathrm{~cm} "$. It was an immature scheme. He had an error in determining the distance of point B to the diagonal of space AG. However, visually ST students can represent their perception of space. He can draw precisely the cube ABCD.EFGH and point A to the edge HG. The student can represent the position between the elements of a cube placed in a horizontal or vertical position. He can predict spatial images as spatial visualizations, despite the difficulty of connecting parts to one another as spatial relations. ST students are in the inter-level classification (Widada, Herawaty, Jumri, et al., 2020). Another study found that students can perform abstraction, idealization, and generalization processes about geometric objects based on real life. Students can do Interiorization and encapsulation in the form of geometric concepts and principles (Widada, Herawaty, Ma'rifah, et al., 2019).

\section{Footage 4}

YP : "Based on Problem 3, I can say that the cube ABCD.EFGH has a side length of $6 \mathrm{~cm}$, and point $\mathrm{P}$ is in the middle of FG. What is the distance between point A and line DP?" Researcher : "Okay. How to solve it?"

YP : "I got a picture of the cube, as shown in Figure 8."

Researcher : “....” 
: "I draw a diagonal line in the space AG and it intersects with DP at the point $\mathrm{T}$. The length of AT is the distance from A to the line DP. I estimate that AT is $2 / 3$ of the length of AG."

Researcher : "What next?"

YP : "The length of AG can be calculated from the diagonal length of the cube space but I forgot how to calculate it."

Researcher : "Remember again how to calculate it?"

YP : "As far as I remember using the root of 2 or the root of 3. That is all Sir."

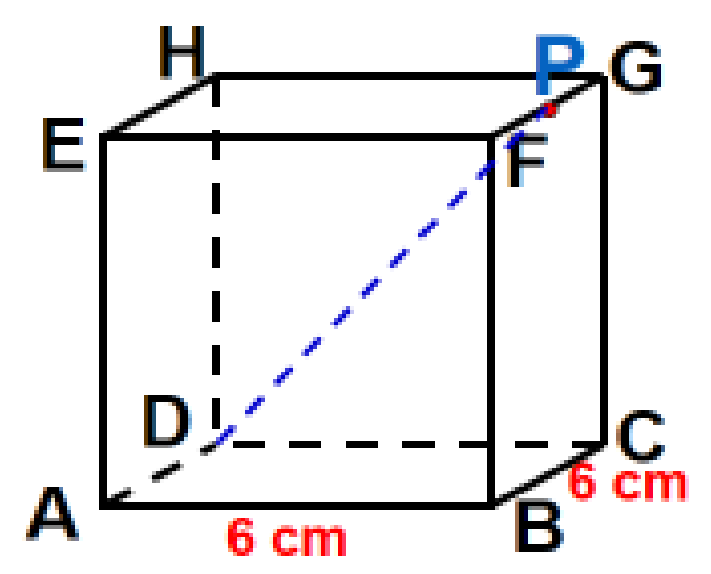

Figure 8. Cube ABCD.EFGH by YP

Based on Figure 8 and Footage 4, the subject of YP shows that he can represent his perception of space. He can correctly draw the cube ABCD.EFGH and the point P and the line DP. It is the position between the elements of a cube placed in a horizontal or vertical position. YP experienced a misconception on the principle of a distance of a point to a line in space. He stated, "I draw a diagonal line of space AG... and it intersects with DP at point T. ... the length of AT is the distance of A to line DP... I estimate AT is $2 / 3$ of the length of AG." It shows that the subject of YP can only perform actions processes and objects separately. He could not encapsulate the process into a new object about the distance of the point to the line in the form of space. This student belongs to the intra-level (Widada, Efendi, Herawaty, \& Nugroho, 2020). Students cannot do Interiorization and encapsulation, so they fail to solve the given problem.

Thirty students were given a pretest and posttest on spatial abilities To determine the effect of the ethnomathematics learning approach during geometry learning. The mean pretest score was 34.57 , and the average posttest score was 77.23. The gain index is 0.78 . It shows that students' spatial ability after being taught geometry by applying a realistic mathematics learning approach has increased relatively high. Therefore, realistic mathematics learning in geometry can make it easier for students to understand the given problems. It also makes it easier for students to make spatial 
perceptions, visualizations, and spatial relations. Thus, it is easy for students to solve the given geometry problems. Other research shows that the ability to understand mathematical concepts of students taught with a realistic mathematics learning approach is higher than students taught by direct learning (Herawaty, Widada, Nugroho, Falaq, \& Anggoro, 2019). The mathematical problemsolving ability of students who learn through local culture with the outdoor learning model is higher than before learning with that model (Widada, Herawaty, Falaq, Anggoro, 2019). Thus, through ethnomathematics learning in geometry learning, mainly geometric shapes, some students reach the highest level of the triad level, namely the trans level. (Cooley, Trigueros, \& Baker, 2007). Based on statistical tests, there is an increase in the spatial understanding of students taught through an ethnomathematics approach.

In my initial research, I found that spatial ability is the ability to imagine, guess, determine, construct, compare, and present visual stimuli in the context of space. It is the relationship between the ability to observe the relationship of the position of objects in space. This study found an increase in the spatial understanding of students who were taught through an ethnomathematics approach. After learning geometry, there are three levels of students' spatial ability through an ethnomathematics approach. Those are the trance level, the inter-level, and the lowest intra-level.

Trans students have a mature schema about the properties of spatial structures. Thematization of objects about the diagonal of the plane and the diagonal of space can be represented in a good mental activity. He can correctly predict the image of the building as a form of spatial visualization.

Visualization skills can be achieved well through learning realistic mathematics and spatial reasoning. The student can understand and apply spatial abilities in daily life. The student can represent the position between the elements of a cube placed in a horizontal or vertical position. He can predict spatial images as spatial visualizations, despite the difficulty of connecting parts to one another as spatial relations. Inter-level students can carry out action-process-object-and schema activities, but the thematization is incomplete. Meanwhile, intra-level students can do spatial perception but cannot do Interiorization and encapsulation, so they fail to solve the given problem.

Based on the research that during learning geometry about Lobachevsky's axioms, students are faced with real problems related to fishing culture using traps. The expected ignition is Lobachevsky's Parallel Line axiom (Herawaty, Khrisnawati, Widada, \& Mundana, 2020). Students use activity sheets to trigger their cognitive processes in understanding and achieving the Parallel 
Line principle. The following is a sequence of students' cognitive processes in understanding axioms. Pay attention to Figure 9.

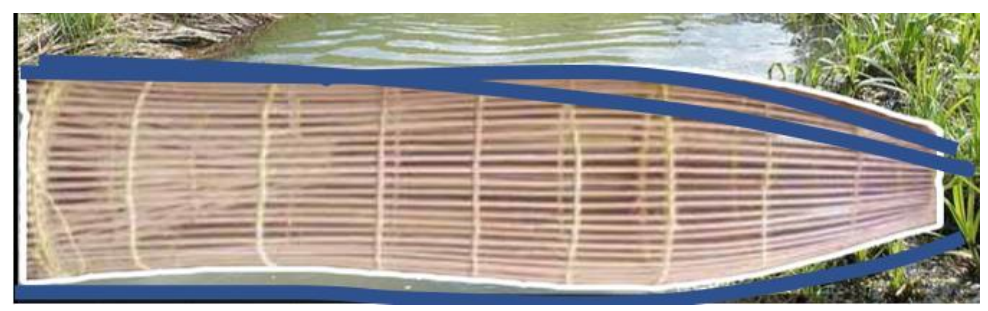

Figure 9. Bubu (Fish Trap)

Through an ethnomathematics approach, the research (Herawaty, Khrisnawati, et al., 2020) found that a student could take action based on the line on the trap (see Figure 9). He internalized the process of moving the outline sketch into the document. Then, the subject can summarize these processes into a Parallel Line object. In addition, students can conclude that there are many lines parallel to $\mathrm{g}$. He can construct statements stored in his information processing system in the form of schemas. The statement is "there is an infinite line parallel to $\mathrm{g}$ ". He states that the statement's background is the point $\mathrm{P}$ outside the line $\mathrm{g}$, the line at infinity is the line through the point $\mathrm{P}$. That is a mature schema that has GS. He stated that students could organize activities and create algorithms that form concepts correctly.

\section{CONCLUSION}

The author concludes that Euclidean geometry has several weaknesses based on the description above. First, Euclid attempted to define all elements in geometry, including points, lines, and planes. Euclid defined a point as one that has no part. He defined a line as length without width. The words "section", "length", and "width" are not found in Euclidean Geometry. Second, almost every part of Euclid's theorem proof uses geometric drawings, but in practice, these drawings are misleading. Local culture and ethnomathematics approaches become teaching materials and student learning trajectories in studying Non-Euclid Geometry.

\section{REFERENCES}

Agusdianita, N., Widada, W., Afriani, N. H., Herawati, H., Herawaty, D., \& Nugroho, K. U. Z. (2021). The exploration of the elementary geometry concepts based on Tabot culture in Bengkulu. Journal of Physics: Conference Series, (1731), 1-11. https://doi.org/10.1088/1742-6596/1731/1/012054

Andriani, D., Widada, W., Herawaty, D., Ardy, H., Nugroho, K. U. Z., Ma'rifah, N., ... Anggoro, A. F. D. (2020). Understanding the number concepts through learning Connected Mathematics (CM): A local cultural approach. Universal Journal of Educational Research, 8(3), 1055-1061. https://doi.org/10.13189/ujer.2020.080340

Baker, B., Cooley, L., \& Trigueros, M. (2000). A Calculus Graphing Schema. Journal for Research in Mathematics Education, 31(5), 557=578. https://doi.org/10.2307/749887

Bosnyak, A., \& Kondor, R. N. (2008). The spatial ability and spatial geometrical knowledge of university students majored in mathematics. Acta Didactica Universitatis Comenianae. Mathematics, (8), 1-25. 
Byrne's Euclid. (1847). The Elements of Euclide. Toronto: Library of The University of Toronto.

Cooley, L., Trigueros, M., \& Baker, B. (2007). Schema Thematization: A Framework and an Example. Journal for Research in Mathematics Education, 38(4), 370-392. https://doi.org/10.2307/30034879

Dilling, F., \& Vogler, A. (2021). Fostering Spatial Ability Through Computer-Aided Design: a Case Study. Digital Experiences in Mathematics Education. https://doi.org/10.1007/s40751-021-00084-w

Dubinsky, E., \& McDonald, M. A. (2000a). APOS: A Constructivist Theory of Learning in Undergraduate Mathematics Education Research. Http:/Www.Telri.Ac.Uk/CM/Paper.Pdf.

Dubinsky, E., \& McDonald, M. A. (2000b). APOS: A Constructivist Theory of Learning in Undergraduate Mathematics Education Research. USA: Georgia State University.

Dubinsky, E., \& Wilson, R. T. (2013). High school students' understanding of the function concept. The Journal of Mathematical Behavior, 32(1), 83-101. https://doi.org/10.1016/s0732-3123(01)00065-7

Dubinsky, E., Dautermann, J., Leron, U., \& Zazkis, R. (1994a). On learning fundamental concepts of group theory. Educational Studies in Mathematics, 27(3), 267-305. https://doi.org/10.1007/BF01273732

Dubinsky, E., Dautermann, J., Leron, U., \& Zazkis, R. (1994b). On learning fundamental concepts of group theory. Educational Studies in Mathematics, 2-38.

Dubinsky, E., Dautermann, J., Leron, U., \& Zazkis, R. (n.d.). On Learning Fundamental Concepts of Group Theory, $O(3762)$.

Dubinsky, E., Weller, K., McDonald, M. A., \& Brown, A. (2004). Same historical issues and paradoxes regarding teh concept of infinity: An APOS based analysis, Part 1.

Eskisehir, O., \& Ozlem, K. (2015). Investigation of the relationship between the spatial visualization success and visual/spatial intelligence capabilities of Sixth Grade students. International Journal of Instruction, 8(1), 189-204.

Fauzan, A., Slettenhaar, D., \& Plomp, T. (2002). Traditional Mathematics Education vs . Realistic Mathematics Education: Hoping for Changes. Proceedings of the 3rd International Mathematics Education and Society Conference. Copenhagen: Centre for Research in Learning Mathematics, 1-4.

François, K. (2010). The Role of Ethnomathematics Within Mathematics Education. Proceedings of Cerme, 1517-1526. https://doi.org/10.1007/978-3-319-12688-3

Frassia, M. G., \& Serpe, A. (2017). Learning Geometry Through Mathematical Modelling: An Example With Geogebra. Turkish Online Journal of Educational Technology, (Special Issue for INTE 2017).

Freudenthal, H. (1991). Revisiting Mathematics Educational. Dordrecht: Reidel Publising.

Gravemeijer, K. (1994). Developing Realistic Mathematics Education. Utrecht: Freudenthal Institute.

Gravemeijer, K. (2008). RME Theory and Mathematics. Tools and Processes in Mathematics Teacher Education, 283-302.

Güven, B., \& Kosa, T. (2008). The effect of dynamic geometry software on student mathematics teachers' spatial visualization skills. Turkish Online Journal of Educational Technology, 7(4), 100-107.

Hankeln, C. (2021). Combining and Contrasting Formal Concept Analysis and APOS Theory. Educational Studies in Mathematics, 105(1), 1-14. https://doi.org/10.1007/s10649-018-9859-7

Heiberg, J. L. (1896). Euclid s Elements of Geometry. edited, and provided with a modern English translation by Richard Fitzpatrick. https://doi.org/10.1038/053241a0

Herawaty, D., Khrisnawati, D., Widada, W., \& Mundana, P. (2020). The cognitive process of students in understanding the parallels axiom through ethnomathematics learning. IOP Conf. Series: Journal of Physics: Conf. Series 1470 (2020) 012077 Doi:10.1088/1742-6596/1470/1/012077, 1470, 1-8. https://doi.org/10.1088/1742-6596/1470/1/012077

Herawaty, D., Widada, W., Adhitya, A., Sari, R. D. W., \& Novianita, L. (2020). Students ' ability to simplify the concept of function through realistic mathematics learning with the ethnomathematics approach. IOP Conf. Series: Journal of Physics: Conf. Series 1470 (2020) 012031 Doi:10.1088/17426596/1470/1/012031, 1470, 1-8. https://doi.org/10.1088/1742-6596/1470/1/012031

Herawaty, D., Widada, W., Nugroho, K. U. Z., Falaq, A., \& Anggoro, D. (2019). The Improvement of the 
Understanding of Mathematical Concepts through the Implementation of Realistic Mathematics Learning and Ethnomathematics. Advances in Social Science, Education and Humanities Research, Volume 295, 295(ICETeP 2018), 21-25.

Ishak, H., Sukestiyarno, Y. L., Waluya, S. B., Rochmad, \& Mariani, S. (2021). Description of student's difficulty in understanding online mathematics learning materials. Journal of Physics: Conference Series, 1918(4). https://doi.org/10.1088/1742-6596/1918/4/042095

Junarti, Sukestiyarno, Y. L., Mulyono, \& Dwidayati, N. K. (2020). The process of structure sense of group prerequisite material: A case in indonesian context. European Journal of Educational Research, 9(3), 1047-1061. https://doi.org/10.12973/EU-JER.9.3.1047

Karadag, Z. (2009). Analyzing Students Mathematical Thinking in Technologie in Technologie-Supported Environments. The University of Toronto. Retrieved from www.statisticshowto.com/wp.../06/Dyscalculia-createspace-v3.pdf

Kayhan, E. B. (2005). Investigation Of High School Students'Spatial Ability.

Kleinman, A. (1987). The Role of Culture. British Journal of Psychiatry, 151, 447-454.

Lubis, A., Widada, W., Herawaty, D., Nugroho, K. U. Z., \& Anggoro, A. F. D. (2021). The ability to solve mathematical problems through realistic mathematics learning based on ethnomathematics. Journal of Physics: Conference Series, (1731), 1-7. https://doi.org/10.1088/1742-6596/1731/1/012050

Maharaj, A. (2010). An APOS Analysis of students' understanding of the concept of a limit of a function. Pythagoras, O(71). https://doi.org/10.4102/pythagoras.v0i71.6

Maharani, H. R., \& Sukestiyarno, Y. L. (2017). Learning analysis based on Humanism Theory and Mathematics Creative Thinking Ability of Students. International Conference on Mathematics: Education, Theory, and Application (ICMETA), 1, 218-225.

Maharani, H. R., Sukestiyarno, Y. L., Waluya, S. B., \& Mulyono, M. (2018). Design of creative thinking test in geometry based on information processing taxonomy model. Beta: Jurnal Tadris Matematika, 11(2), 144-155. https://doi.org/10.20414/betajtm.v11i2.180

Maier, P. H. (1998). Spatial Geometry and Spatial Ability - Hoe to Make Solid Geometry Solid? Selected Papers from the Annual Conference of Didactics of Mathematics 1996. Elmar Cohors-Fresenborg et All (Ed).. Osnabrueck, 1998, 69-81.

Marunić, G., \& Glažar, V. (2014). Improvement and assessment of spatial ability in engineering education. Engineering Review, 34(2), 139-150.

Nugroho, K. U. Z., Widada, W., \& Herawaty, D. (2019). The Ability To Solve Mathematical Problems Through Youtube Based Ethnomathematics Learning. International Journal of Scientific \& Technology Research, 8(10), 1232-1237.

Nugroho, K. U. Z., Widada, W., Herawaty, D., Panduwinata, B., \& Sospolita, N. (2021). Abstraction Ability of Students About Fractions Through Local Cultural Approaches. Advances in Social Science, Education and Humanities Research, (532), 480-485.

Plomp, T., \& Nieveen, N. (2013). Educational Design Research Educational Design Research. Educational Design Research, (July), 1-206. https://doi.org/10.1007/978-1-4614-3185-5_11

Rosa, M., \& Orey, D. C. (2011). Ethnomathematics: the cultural aspects of mathematics. Revista Latinoamericana de Etnomatemática, 4(2), 32-54.

Sukestiyarno, Y. L., Mashitoh, N. L. D., \& Wardono, W. (2021). Analysis of Students' Mathematical Creative Thinking Ability in Module-assisted Online Learning in terms of Self-efficacy. Jurnal Didaktik Matematika, 8(1), 106-118. https://doi.org/10.24815/jdm.v8i1.19898

Treffers, A. (1991). Didactical background of a mathematics program for primary education. In L. Streefland (ed.), Realis tic Mathematics Education in Primary School, CD- $\beta$ Press / Freudenthal Institute. Utrecht University. Utrecht: Freudenthal Institute.

Widada, W, Agustina, A., Serlis, S., Dinata, B. M., \& Hasari, S. T. (2019). The abstraction ability of students in understanding the concept of geometry The abstraction ability of students in understanding the concept of geometry. Journal of Physics: Conference Series, 1318(012082), 1-7. https://doi.org/10.1088/1742$6596 / 1318 / 1 / 012082$ 
Widada, W, Herawaty, D., Hudiria, I., Prakoso, Y. A., Anggraeni, Y. R., \& Zaid, K. U. (2020). The understanding of the triangle in Lobachevsky Geometry through local culture. International Seminar on Applied Mathematics and Mathematics Education 2020 (2nd ISAMME 2020). Journal of Physics: Conference Series, 1657(012038), 1-7. https://doi.org/10.1088/1742-6596/1657/1/012038

Widada, W, Herawaty, D., Jumri, R., \& Wulandari, H. (2020). Students of the extended abstract in proving Lobachevsky's parallel lines theorem. IOP Conf. Series: Journal of Physics: Conf. Series 1470 (2020) 012098 Doi:10.1088/1742-6596/1470/1/012098, 1470, 1-10. https://doi.org/10.1088/17426596/1470/1/012098

Widada, W, Herawaty, D., Widiarti, Y., Aisyah, S., \& Tuzzahra, R. (2020). The cognitive process of students in understanding the triangles in Geometry of Riemann through local content. International Seminar on Applied Mathematics and Mathematics Education 2020 (2nd ISAMME 2020). Journal of Physics: Conference Series, 1657(012033), 1-8. https://doi.org/10.1088/1742-6596/1657/1/012033

Widada, W. (2002). Teori APOS sebagai suatu alat analisis dekomposisi genetik terhadap perkembangan konsep matematika seseorang. Journal of Indonesian Mathematicel Society (MIHMI), 8.

Widada, W. (2007). Development of triad level theory of calculus for mathematics students. Jurnal Inspirasi, $5(1), 1-12$.

Widada, W. (2011). Mathematics Learning towards Extended Trans Level. Bengkulu: Program Pascacarjana Pendidikan Matematika Universitas Bengkulu.

Widada, W. (2016). Profile Of Cognitive Structure Of Students In Understanding The Concept Of Real Analysis. Journal of Mathematics Education (Infinity), $\quad 5(2), \quad 83-98$. https://doi.org/10.22460/infinity.v5i2.215

Widada, W. (2017). Beberapa Dekomposisi Genetik Siswa dalam Memahami Matematika. Jurnal Pendidikan Matematika Raflesia, 1(1), 44-54.

Widada, W., Efendi, S., Herawaty, D., \& Nugroho, K. U. Z. (2020). The genetic decomposition of students about infinite series through the ethnomathematics of Bengkulu, Indonesia. IOP Conf. Series: Journal of Physics: Conf. Series 1470 (2020) 012078 Doi:10.1088/1742-6596/1470/1/012078, 1470, 1-9. https://doi.org/10.1088/1742-6596/1470/1/012078

Widada, W., Herawaty, D., \& Lubis, A. N. M. T. (2018). Realistic mathematics learning based on the ethnomathematics in Bengkulu to improve students' cognitive level. Journal of Physics: Conference Series, 1088. https://doi.org/10.1088/1742-6596/1088/1/012028

Widada, W., Herawaty, D., Anggoro, A. F. D., \& Nugroho, K. U. Z. (2019). The Trans Level Characteristics About Infinite Series. J U M A D I K A Jurnal Magister Pendidikan Matematika, 1(1), 19-24.

Widada, W., Herawaty, D., Beka, Y., Sari, R. M., \& Riyani, R. (2020). The mathematization process of students to understand the concept of vectors through learning realistic mathematics and ethnomathematics. IOP Conf. Series: Journal of Physics: Conf. Series 1470 (2020) 012071 Doi:10.1088/17426596/1470/1/012071, 1470, 1-10. https://doi.org/10.1088/1742-6596/1470/1/012071

Widada, W., Herawaty, D., Falaq, A., Anggoro, D., Yudha, A., \& Hayati, M. K. (2019). Ethnomathematics and Outdoor Learning to Improve Problem Solving Ability. Advances in Social Science, Education and Humanities Research, Volume 295, 295(ICETeP 2018), 13-16.

Widada, W., Herawaty, D., Ma'rifah, N., \& Yunita, D. (2019). Characteristics of Students Thinking in Understanding Geometry in Learning Ethnomathematics. International Journal of Scientific \& Technology Research, 8(11), 3496-3503.

Widada, W., Herawaty, D., Nugroho, K. U. Z., \& Anggoro, A. F. D. (2019). The ability to Understanding of the Concept of Derivative Functions for Inter-Level Students During Ethnomathematics Learning. Journal of Physics: Conference Series, 1179(012056), 1-6. https://doi.org/10.1088/17426596/1179/1/012056

Widada, W., Nugroho, K. U. Z., Sari, W. P., \& Pambudi, G. A. (2019). The ability of mathematical representation through realistic mathematics learning based on ethnomathematics. Journal of Physics: Conference Series, 1318(012073), 1-8. https://doi.org/10.1088/1742-6596/1318/1/012073

Widada, W., Nugroho, K. U. Z., Sari, W. P., \& Pambudi, G. A. (2019). Characteristics of Students Thinking in Understanding Geometry in Learning Ethnomathematics. Journal of Physics: Conference Series, 
1318(3), 1-6. https://doi.org/10.1088/1742-6596/1179/1/012056

Wu, D., \& Ma, H. (2006). The Distributions of Van Hiele Levels of Geometric Thinking Among 1st Through 6th Graders. Proceedings 30th Conference of the International Group for the Psychology of Mathematics Education, 5, 409-416.

Yurt, E., \& Tünkler, V. (2016). A study on the spatial abilities of prospective social studies teachers: A mixedmethod research. Kuram ve Uygulamada Egitim Bilimleri, 16(3), 965-986. https://doi.org/10.12738/estp.2016.3.0324 